\title{
Why pygmy snails lay giant eggs: the Kiwi Syndrome
}

\author{
Julián Monge-Nájera \\ Laboratorio de Ecología Urbana, Universidad Estatal a Distancia, 2050 San José, Costa \\ Rica; jmonge@uned.com
}

\begin{abstract}
АвSTRAст: Some minute land snails lay disproportionally large eggs, and the reason is unknown. Here I present the hypothesis that it results from the "Kiwi Syndrome", in which natural selection pressures - associated with low egg predation, heavy predation of the young, and a minimal viable size for hatchlings - force small females to invest in relatively large offspring at the cost of reduced fecundity.
\end{abstract}

KEY WORDS: Punctum pygmaeum, egg size, predation, fecundity, Apteryx.

Minute leaf litter snails tend to have unexpectedly large eggs (Baur, 1989; Barrientos, 2000), for example, the pygmy snail, Punctum pygmaeum, lays eggs that are 0.41 by $0.50 \mathrm{~mm}$, or about one third the size of the mother (Baur, 1989).

Baur (1989) suggested that there was some unknown structural or physiological constraint preventing the production of eggs smaller than $0.40 \mathrm{~mm}$ in diameter. Barrientos (2000) suggested that the constraint for small eggs in a land snail could be a minimal quantity of nutrients needed for a viable egg, and presented the case of Ovachlamys fulgens, a land snail that maybe had larger ancestors and has difficulties laying its oversized eggs; to be able to lay these eggs, the snail has to invaginate its four tentacles and lays partially dehydrated eggs that absorb moisture from the substrate to reach their final size (Barrientos, 2000).

Egg size is unknown for the smallest land snails (Páll-Gergely, Hunyadi, Jochum, \& Asami, 2015), but at least the idea of minimal size for a viable egg has a parallel in another group: in velvet worms, there is a minimal size for viable offspring, and small females are forced to give birth to large babies at the cost of reduced fecundity (Monge-Nájera, 1994). A similar case among vertebrates is the kiwi (a general name given to five bird species of genus Apteryx), which produces a single egg that occupies much of the mother's body cavity.

Kiwis were originally believed to have large eggs because they were dwarf descendants of a giant bird (Calder, 1978). However, later evidence indicated a radically different explanation: that kiwis had a small ancestor and that they have duplicated body size and increased egg size enormously (Worthy et al., 2013).

Worthy et al. (2013) proposed, as a possible reason, that kiwi eggs are relatively safe, while kiwis suffer most predation in the weeks following hatching. This matches field evidence: only $10 \%$ of eggs are eaten by predators, but $90 \%$ of 
kiwis die from predation before reaching reproductive age (McLennan et al., 1996).

Like kiwis (Bain, 2018), some small land snails need moist environments; are not agile; have unexpectedly long lifespans (Finch, 1994, p. 13; Kuźnik-Kowalska \& Proćków, 2016); lay relatively large eggs with little individual variation (Baur, 1994); and invest resources in large offspring with better survival rates (Baur \& Raboud, 1988). Perhaps kiwis, and snails with this list of characteristics, which I will call the "Kiwi Syndrome", have been exposed to evolutionary pressures that include low egg predation, heavy predation on the young, and a minimal viable size for hatchlings, forcing small snails to invest in relatively large offspring at the cost of reduced fecundity.

\section{REFERENCES}

Bain, I. A. (2018). Egg-size variation in North Island brown kiwi (Apteryx mantelli): influences and consequences (thesis). University of Canterbury, New Zealand.

Barrientos, Z. (2000). Population dynamics and spatial distribution of the terrestrial snail Ovachlamys fulgens (Stylommatophora: Helicarionidae) in a tropical environment. Revista de Biología Tropical, 48(1), 7187.

Baur, B. (1989). Growth and reproduction of the minute land snail Punctum pygmaeum (Draparnaud). Journal of Molluscan Studies, 55(3), 383-387.

Baur, A. (1994). Within- and between- clutch variation in egg size and nutrient content in the land snail Arianta arbustorum. Functional Ecology, 8(5), 581-586.

Baur, B., \& Raboud, C. (1988). Life history of the land snail Arianta arbustorum along an altitudinal gradient. The Journal of Animal Ecology, 57(1), 71-87.

Calder, W. A. (1978). The kiwi. Scientific American, 239(1), 132-143.

Finch, C. E. (1994). Longevity, senescence, and the genome. Chicago: University of Chicago Press.

Kuźnik-Kowalska, E., \& Proćków, M. (2016). Reproductive biology and growth of two Vallonia species in laboratory conditions (Gastropoda: Eupulmonata: Valloniidae). Folia Malacologica, 24(4), 265-273.

McLennan, J. A., Potter, M. A., Robertson, H. A., Wake, G. C., Colbourne, R., Dew, L., ... \& Reid, J. (1996). Role of predation in the decline of kiwi, Apteryx spp., in New Zealand. New Zealand Journal of Ecology, 20(1), 27-35.

Monge-Nájera, J. (1994). Reproductive trends, habitat type and body characteristics in velvet worms (Onychophora). Revista de Biología Tropical, 42(3), 611-622.

Páll-Gergely, B., Hunyadi, A., Jochum, A., \& Asami, T. (2015). Seven new hypselostomatid species from China, including some of the world's smallest land snails (Gastropoda, Pulmonata, Orthurethra). ZooKeys, 523, 31-62.

Worthy, T., Worthy, J. P., Tennyson, A. J., Salisbury, S. W., Hand, S. J., \& Scofield, R. P. (2013). Miocene fossils show that kiwi (Apteryx, Apterygidae) are probably not phyletic dwarves (p. 63-80.). Proceedings of the 8th International Meeting, Society of Avian Palentology and Evolution, Wien, Austria. 
Charles Darwin In Memoriam, a column of Revista de Biología Tropical, welcomes evolutionary looks at the why of biological and cultural phenomena. This entry was reviewed by Zaidett Barrientos and edited by Carolina Seas. 